\title{
FCGR1A Gene
}

National Cancer Institute

\section{Source}

National Cancer Institute. FCGR1A Gene. NCI Thesaurus. Code C104234.

This gene is involved in the immune response. 